\title{
Evolutionarily conserved genetic interactions with budding and fission yeast MutS identify orthologous relationships in mismatch repair-deficient cancer cells
}

Elena Tosti ${ }^{1}$, Joseph A Katakowski², Sonja Schaetzlein ${ }^{1}$, Hyun-Soo Kim¹', Colm J Ryan ${ }^{3,4,5}$, Michael Shales ${ }^{3}$, Assen Roguev ${ }^{3}$, Nevan J Krogan ${ }^{3,4,6}$, Deborah Palliser ${ }^{2}$, Michael-Christopher Keogh ${ }^{1^{*}}$ and Winfried Edelmann ${ }^{{ }^{*}}$

\begin{abstract}
Background: The evolutionarily conserved DNA mismatch repair (MMR) system corrects base-substitution and insertion-deletion mutations generated during erroneous replication. The mutation or inactivation of many MMR factors strongly predisposes to cancer, where the resulting tumors often display resistance to standard chemotherapeutics. A new direction to develop targeted therapies is the harnessing of synthetic genetic interactions, where the simultaneous loss of two otherwise non-essential factors leads to reduced cell fitness or death. High-throughput screening in human cells to directly identify such interactors for disease-relevant genes is now widespread, but often requires extensive case-by-case optimization. Here we asked if conserved genetic interactors (CGIs) with MMR genes from two evolutionary distant yeast species (Saccharomyces cerevisiae and Schizosaccharomyzes pombe) can predict orthologous genetic relationships in higher eukaryotes.
\end{abstract}

Methods: High-throughput screening was used to identify genetic interaction profiles for the MutSa and MutS $\beta$ heterodimer subunits ( $m s h 2 \Delta, m s h 3 \Delta, m s h 6 \Delta$ ) of fission yeast. Selected negative interactors with MutS $\beta$ ( $m s h 2 \Delta / m s h 3 \Delta$ ) were directly analyzed in budding yeast, and the CGI with SUMO-protease UIp2 further examined after RNA interference/drug treatment in MSH2-deficient and -proficient human cells.

Results: This study identified distinct genetic profiles for MutSa and MutS $\beta$, and supports a role for the latter in recombinatorial DNA repair. Approximately $28 \%$ of orthologous genetic interactions with $m s h 2 \Delta / m s h 3 \Delta$ are conserved in both yeasts, a degree consistent with global trends across these species. Further, the CGI between budding/fission yeast msh2 and SUMO-protease UIp2 is maintained in human cells (MSH2/SENP6), and enhanced by Olaparib, a PARP inhibitor that induces the accumulation of single-strand DNA breaks. This identifies SENP6 as a promising new target for the treatment of MMR-deficient cancers.

Conclusion: Our findings demonstrate the utility of employing evolutionary distance in tractable lower eukaryotes to predict orthologous genetic relationships in higher eukaryotes. Moreover, we provide novel insights into the genome maintenance functions of a critical DNA repair complex and propose a promising targeted treatment for MMR deficient tumors.

\footnotetext{
* Correspondence:

michael.keogh@einstein.yu.edu; winfried.edelmann@einstein.yu.edu

'Department of Cell Biology, Albert Einstein College of Medicine, New York, USA

Full list of author information is available at the end of the article
}

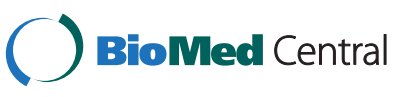

(c) 2014 Tosti et al.; licensee BioMed Central Ltd. This is an Open Access article distributed under the terms of the Creative Commons Attribution License (http://creativecommons.org/licenses/by/4.0), which permits unrestricted use, distribution, and reproduction in any medium, provided the original work is properly credited. The Creative Commons Public Domain Dedication waiver (http://creativecommons.org/publicdomain/zero/1.0/) applies to the data made available in this article, unless otherwise stated. 


\section{Background}

Defective DNA mismatch repair (MMR) is the underlying cause of hereditary non-polyposis colorectal cancer/Lynch syndrome (HNPCC/LS) and a significant proportion of sporadic colorectal cancers (CRCs) $[1,2]$. The MMR genes most frequently mutated or epigentically silenced in these cancers are MSH2 and MLH1, which respectively function in the coordination of mismatch recognition and excision $[3,4]$. The characteristic repair steps in MMR are highly conserved in bacteria, yeast, and mammals. In eukaryotes, the efficient recognition of distinct mismatches requires subsets of three different homologs of bacterial mutS: the MutSa heterodimer (MSH2-MSH6) initiates the repair of single-base mispairs and single-base insertion/deletions (IDLs), while MutS $\beta$ (MSH2-MSH3) primarily initiates the repair of larger IDLs of two to four bases but also facilitates the restoration of single-base mismatches [5] (Figure 1A). Subsequent to mismatch recognition MutS $\alpha$ or MutS $\beta$ interact with MutL $\alpha$ (MLH1-PMS2) in an
ATP-dependent manner to initiate excision of the appropriate DNA strand [3]. During this process individual MutS and MutL subunits directly interact with PCNA, RFC, and RPA, indicating that mismatch excision is closely correlated with DNA replication [3].

As a consequence of their defective MMR, HNPCC/ LS tumors and sporadic CRCs display increased rates of replication errors at short repeat sequences, termed microsatellite instability (MSI). MSI-positive tumors exhibit resistance to DNA damaging agents, and thus respond poorly to conventional chemotherapy $[12,13]$. Of additional concern, the treatment of these patients with chemotherapeutic agents can induce secondary therapy-related leukemias (for example, acute myeloid leukemia/myelodysplastic syndrome) [14,15]. Indeed it has been suggested that the primary treatment of HNPCC/LS with chemotherapeutics actually selects for hematopoietic precursor cells with MMR-defects [16]. As these cells proliferate they accumulate further mutations and develop
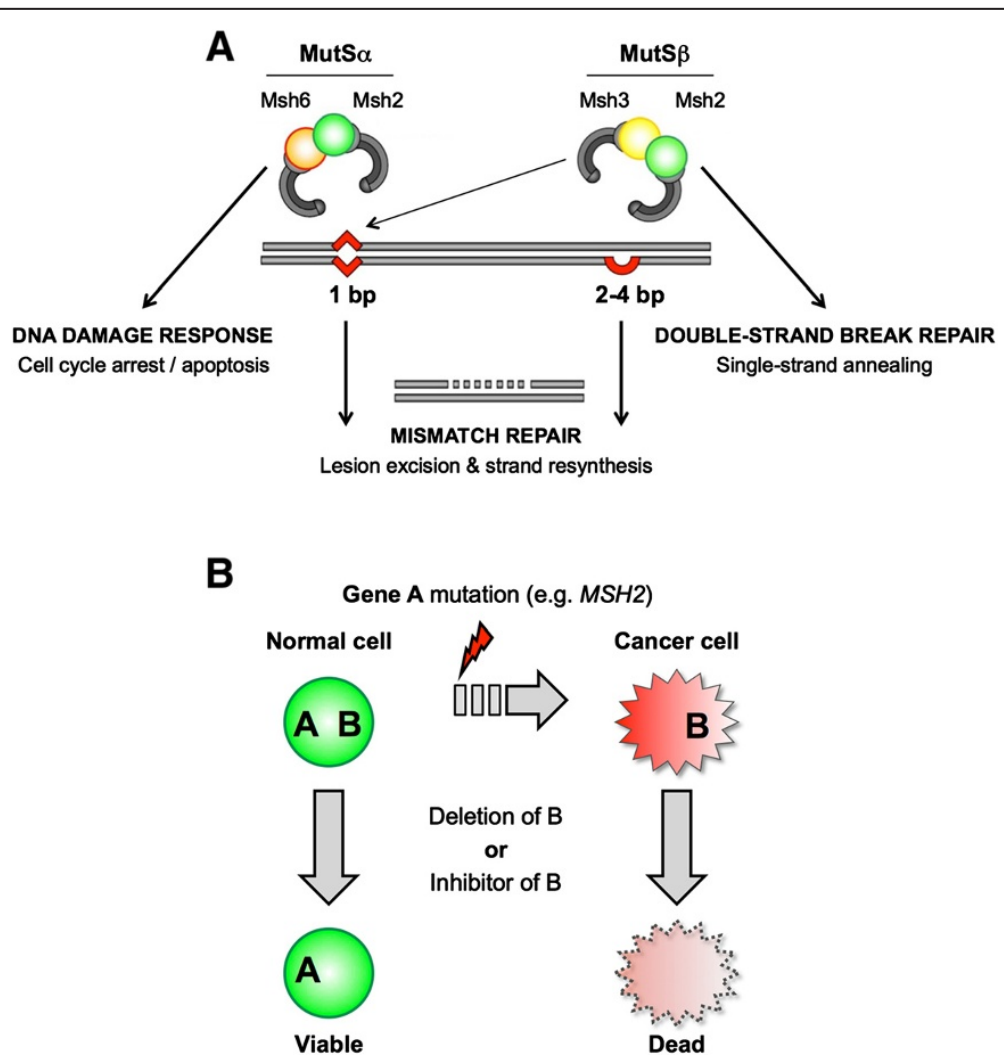

Figure 1 Synthetic lethality as a therapeutic strategy for the treatment of MMR-deficient cancers. (A) DNA mismatch repair is a stepwise process. In the schematic the MutSa heterodimer (Msh2-Msh6) recognizes a single-base mispair while MutS $\beta$ (Msh2-Msh3) primarily (but not exclusively [6-9]) initiates the repair of larger insertions/deletions (IDLs) of two to four bases. Recognition activates the recruitment of MutLa (Mlh1-Pms2) and multiple downstream factors (for example, Exo1, PCNA, RFC, RPA, and DNA pol 8) for repair by lesion excision and strand resynthesis. Each MutS also has roles independent of these downstream effectors of MMR: as an example, MutSa associates with cell cycle regulators at sites of DNA damage to mediate arrest and apoptosis [3], while MutS $\beta$ contributes to the repair of double-strand breaks via recombinatorial single-strand annealing [10,11]. Mutations in many factors from this pathway are associated with cancer. (B) Loss of A (for example, MSH2) is a common initiating event in many colorectal cancers. Candidate screening seeks to identify and exploit negative genetic relationships (synthetic sick/lethal) to selectively kill cells that harbor the MSH2 deficiency, but spare those lacking this cancer-related alteration. 
increased resistance to anticancer agents. Thus the development of novel therapeutic strategies that efficiently and selectively target the primary MMR-deficient cancer but avoids therapy-induced secondary tumors would be highly desirable.

A promising new direction to develop targeted therapies is the harnessing of synthetic genetic interactions, where the simultaneous loss of two otherwise non-essential factors leads to reduced cell fitness (synthetic sickness (SS)) or cell death (synthetic lethality $(\mathrm{SL}))[17,18]$. This provides great functional insight: an SS/SL interaction for two alleles often indicates that their gene products are in parallel pathways or impinge on the same essential function. However it can also provide an elegant strategy to selectively eliminate tumor cells that harbor specific cancer-causing mutations. In this manner, the protein products of genes SS/SL to cancer-causing mutations represent potential drug targets (Figure 1B). As an example, inhibitors of poly-ADP-ribose polymerase I (PARP; required for the repair of single-stranded DNA breaks) are lethal to cells with deficiencies in BRCA1 or $B R C A 2$ and show promise in the treatment of breast cancer $[19,20]$.

A range of approaches can be used to search for SS/SL interactions with therapeutic intent, the most direct being RNA interference-based screening by si/shRNA libraries in human cells $[21,22]$. Although RNAi lends itself to high-throughput, incomplete knockdowns or off-target effects are commonly observed, and the large scaleformat precludes single-case optimization. There are additional issues related to cost, that robotic sample handling might limit the type of read-out assay, the requirement for easily transfectable cell-lines, and even the possibility that an SS/SL interaction might be celltype specific. Despite these potential concerns, various studies describe the successful application of highthroughput RNAi-based approaches to investigate mammalian gene function [21-24]. Indeed recent analyses identified the synthetic combinations $M S H 2 / D N A$ pol $\beta, M L H 1 / \mathrm{DNA}$ pol $\gamma$, and $M S H 2 /$ dihydrofolate reductase $[25,26]$. This directly demonstrates the existence of SS/SL interactions for mammalian MMR genes, although both DNA polymerases are essential in knockout mice and contribute to high-fidelity replication in dividing cells $[27,28]$, which may limit their potential as therapeutic targets.

Genetic interaction screening in tractable model organisms constitutes a powerful alternative approach for candidate identification. Defining the function of a gene product in budding and fission yeasts (Saccharomyces cerevisiae $(S c)$ and Schizosaccharomyces pombe $(S p)$, respectively) has proven highly predictive of the role of its metazoan ortholog $[29,30]$. These yeasts separated approximately 380 million years ago [31] (by comparison, the last common predecessor of the entire mammalian class existed about 165 mya [32]), but share substantial gene content, with approximately $75 \%$ of $S p$ genes having one or more $S c$ orthologs [33-35]. This high level of conservation commonly extends to functional units, such that many yeast complexes are reminiscent of their metazoan counterparts [36,37]. High-throughput genetic interaction mapping approaches have been developed for both yeasts to evaluate the genetic interactions of null, hypomorphic, or mutant alleles in a genome-wide manner [33,34,38]. These techniques, in combination with the comprehensive deletion libraries available for both species [35,39], have been used to provide an overview of the functional dependencies within eukaryotic cells, and give insight into both the function of individual genes and the organization of biological systems [40-42]. Furthermore, cross species comparison has identified a high conservation (19\% to $29 \%$ ) of SS/SL interactions between orthologous gene pairs in $S c$ and $S p$ [33,34,41,42].

Here we surmised that complementary genetic analyses of specific MMR genes in the evolutionary distant $S$. cerevisiae and $S$. pombe could be used to dissect the function(s) of each individual factor. We further posited that screening against non-essential gene deletions could maximize the potential of identifying SS/SL interactions with potential therapeutic utility. Moreover the identification of Conserved Genetic Interactors (CGIs: SS/SL in both yeasts) could then be tested as candidate drug targets in MSI-positive CRC cell lines. An obvious potential limitation of this approach is the requirement for a high degree of conservation between the yeast and human orthologs. In this regard the MMR factors are particularly well conserved across evolution, which extends to preserving the same repair functions [43]: thus CGIs for each yeast gene might be expected to have strong predictive power for their mammalian orthologs.

\section{Methods}

\section{In situ mutagenesis}

Constructs for de novo gene deletion were assembled by PCR megapriming from budding or fission yeast genomic DNA and plasmid templates [44,45]. The resulting products were transformed/targeted by homologous recombination in the desired budding or fission yeast backgrounds and confirmed by sequencing and/or phenotypic analyses as appropriate [46].

PEM2 (Pombe Epistatic Mapping) analyses in fission yeast Genetic screening in fission yeast used the PEM-2 approach $[34,47]$. In brief, NAT-marked (encoding nourseothricin resistance) queries in the PEM-2 background (p392; KFP171) were crossed to a library of 1,955 nonessential gene deletions, with mating, haploid selection, data acquisition, and analysis as previously. Specific 
interactions of interest were further examined by direct mating, tetrad dissection and spot-testing. Pairwise correlation coefficients (CCs) to examine any relationship between genetic screens were calculated by the CORREL function in Excel [42].

\section{Approaches in saccharomyces cerevisiae}

Many MMR factors participate in meiosis [48], such that some genetic interactions in fission yeast could be the result of a meiotic defect rather than manifesting during mitotic growth. To avoid this possibility genetic interactions in budding yeast were examined after direct transformation, plasmid shuffling by 5 -fluoroorotic acid (5-FOA) selection, and spot-testing. In brief, specific deletions (as KAN cassettes flanked by approximately $500 \mathrm{bp}$ of genomic sequence) were amplified from the relevant heterozygous diploid library strain (Open Biosystems), transformed to the appropriate $m s h 2 \Delta$ or $m s h 3 \Delta$ shuffle strain (with each NAT-marked genomic deletion covered by the relevant wild-type allele on a low-copy URA3 containing plasmid), and homologous-integration events identified by PCR. Replicate clones were successively grown on media containing uracil (to allow loss of the $U R A 3$ plasmid) and 5-FOA (converted to a toxic metabolite in the presence of a functional URA pathway, thus isolating double deletion cells). Spot-testing was then performed to evaluate the fitness of the double deletion clones versus their single deletion parents. Any sensitivity to genotoxins was investigated by spotting onto solid media with various concentrations of each agent: camptothecin (CPT) $(5,7.5$, and $10 \mu \mathrm{M})$, methyl methanesulfonate (MMS) $(0.005 \%, 0.075 \%$, and $0.01 \%)$, hydroxyurea ( $\mathrm{HU})(5 \mathrm{mM}, 7.5 \mathrm{mM}$, and $10 \mathrm{mM})$, or 5-fluorouracil (5-FU) (38 $\mu \mathrm{M}$ and $76 \mu \mathrm{M})$. Strains were spotted as 10-fold serial dilutions onto the relevant plates and growth examined at 48, 72, and $96 \mathrm{~h}$.

\section{Approaches in mammalian cells}

Standard methods were used to examine any genetic interactions in the $\mathrm{MSH} 2$-deficient human endometrial cancer cell line HEC59 $\left(\mathrm{MSH}^{-}\right)$and its isogenic chromosome 2-complemented counterpart $\left(\mathrm{MSH}^{+}\right)$[49]. Transfections with siRNAs (Dharmacon; sequences in Additional file 1) and the TransIT-siQUEST (Mirus) reagent were performed in six-well plates by specific optimization of the manufacturer's suggested conditions. Total RNA was isolated by the RNeasy plus kit (Qiagen) 24 h after siRNA transfection, cDNA synthesized with random hexamers and the Superscript III reverse transcriptase (Invitrogen), and specific transcript levels measured by qPCR (after pre-amplification if required) [50]. SENP6 protein levels in permeabilized cells $48 \mathrm{~h}$ after siRNA transfection were measured by fluorescence cytometry after successive staining with monoclonal mouse anti-human SENP6 (Novus
Biologicals) (or an isotype control antibody: eBioscience) and anti-mouse IgG2a-PE (eBioscience) (Additional file 1: Figure S1). Apoptosis in specific populations was quantified by activated caspase 3 . In brief, cells were trypsinized, stained with LIVE/DEAD fixable violet (Invitrogen), fixed with $2 \%$ paraformaldehyde, and permeabilized with $0.3 \%$ saponin. Each sample was then successively stained with rabbit anti-caspase 3 (Cell Signaling Technology) and goat anti-rabbit IgG-Alexa488 (Molecular Probes), and analyzed by fluorescence cytometry. DNA double strand break levels in specific populations was quantified by $\gamma \mathrm{H} 2 \mathrm{AX}$. In brief, $72 \mathrm{~h}$ after siRNA transfection/24 h after PARP inhibition (20 $\mu \mathrm{M}$ olaparib), cells were permeabilized with Transcription Factor Buffer (BD Pharmingen), successively stained with rabbit anti- $\gamma \mathrm{H} 2 \mathrm{AX}$ (Cell Signaling Technologies) and goat anti-rabbit IgG-Alexa488, and analyzed by fluorescence cytometry. To estimate clonogenic survival, cells were re-plated $72 \mathrm{~h}$ after siRNA transfection/24 h after PARP inhibition ( $5 \mu \mathrm{M}$ olaparib). In brief, cells were collected after each treatment (of triplicate wells), resuspended in the same volume of media, diluted $1 / 500$, and an equal aliquot from each sample re-plated and incubated for 2 weeks. Cells were fixed with $2 \%$ paraformaldehyde, stained with crystal violet, colonies counted, and the clonogenic potential after each treatment of each population expressed relative to the respective siNT-1 (no drug).

\section{Results and discussion}

For this study three specific MMR genes involved in mismatch recognition (MSH2, MSH3, and MSH6, comprising subunits of the MutS $\alpha$ and $\beta$ heterodimers: Figure 1A) were chosen for direct analysis. $\mathrm{MSH}^{-1-}$ mice have late onset intestinal tumors and MSH3-deficiency modifies the tumor spectrum of p53 mutant mice [10,51]. MSH3 mutations are rarely seen in HNPCC/LS, although frame-shifts at repeat sequences within the gene are frequently detected in MSI positive CRCs [2,52,53]. MSH2 is frequently mutated in HNPCC/LS, while MSH6 mutations are more rare (although $M S H 6$, like $M S H 3$, is also commonly frame-shifted in MSI positive CRCs [52,54]). Thus the specific genetic interactors of each gene could identify novel therapeutic targets for these conditions. Comprehensive genetic interaction data for all three factors would also be expected to distinguish the relationship of MutS $\alpha$ and MutS $\beta$ with other repair pathways or biological processes.

\section{Genetic interaction profiling distinguishes fission yeast MutSa and MutS $\beta$}

Appropriate deletion strains (for example, $m s h 2 \Delta:: N A T$ ) were mated to a library of 1,955 deletions (approximately $52 \%$ of the non-essential $S p$ genome [35]), and doublemutant haploid daughters selected with the Pombe Epistatic Mapper-2 (PEM-2) approach [34,47] (see Methods). 
We then used colony size (compared in high-throughput by photography and image analysis) as a quantitative readout to derive scores covering each negative genetic interaction $(<-2.5: \mathrm{SS} / \mathrm{SL})[34,42]$. Of note, the deletion of $m s h 3$ leads to a modest increase in mutation rates [55], while $m s h 2 \Delta$ or $m s h 6 \Delta$ each reduce the fidelity of DNA replication $>100$-fold in S. pombe [56], S. cerevisiae [55] and mammals [57]. The resulting accumulation of secondary mutations had the potential to compromise our genetic screening, so multiple independent clones of each deletion were analyzed to obtain a high-quality dataset (Figure 2A). To date we have screened 953 query alleles against an array of 1,955 non-essential deletions and comprehensive benchmarking confirms the value of this resource: known SS/SL interactions are reproduced, and protein-protein interactions are accurately predicted $[34,42]$. Analysis of the $m s h 2 \Delta$, $m s h 3 \Delta$, and $m s h 6 \Delta$ replicates confirm these global trends, with their data being highly correlated (Pearson correlation co-efficient $(C C)>0.4$ ) indicating that individual SS/SL predictions are highly reproducible (for example, Figure $2 \mathrm{~A}$ and $\mathrm{B}$ ).

The genetic interaction (GI) profile of a mutant allele comprises its set of interacting partners, or in the case of our quantitative screening, the set of scores for these interactions (for example, Figure 2A). GI profiles have been used to predict gene function with high confidence, while the degree of similarity to other mutant profiles can reveal how groups of gene products cooperate in higher-level biological processes [34,42,60,61]. As an example, Msh2 enters into heterodimeric complexes with Msh3 and Msh6, so it might be expected that the set of genetic interactions for $m s h 2 \Delta$ would encompass those observed on deletion of both its partners. Alternatively, since MutS $\alpha$ (Msh2-Msh6) is sufficient for the majority of fission yeast MMR [56], the genetic interactions for $m s h 2 \Delta$ and $m s h 6 \Delta$ could have been very similar. To investigate this we compared the profile for each $m s h \Delta$ within our $(953 \times 1,955)$ dataset [42], with significant relatedness considered a Pearson CC $>0.3[34,42,60]$. In this approach $m s h 2 \Delta$ had no discernible relationship to $m s h 6 \Delta$, but was instead highly correlated with $m s h 3 \Delta$ (Figure 2B). We considered that $m s h 2$ and $m s h 3$ may be genetically related by their loss of function in a process other than MMR. Budding yeast MutS $\beta$ also acts with the Rad1-Rad10 nuclease to remove non-complementary tails during DNA DSB repair by homologous recombination [11] (Figure 1A). We thus noted with interest that the GI profiles of $m s h 2$ and $m s h 3$ were both highly correlated with those of fml1 (Sc Mph1; ATP-dependent 3' to 5' DNA helicase, FANCM ortholog), rhp55 and rhp57 (both RecA family ATPases), and rhp51 (Sc Rad51; RecA family recombinase) (Figure $2 \mathrm{~B}$ ), all of which regulate DNA double-strand break (DSB) repair by recombination $[62,63]$. Thus the similar GI profiles of fission yeast $m s h 2 \Delta$ and msh $3 \Delta$ might be due to their shared role in recombinatorial rather than mismatch repair $[58,64,65]$.

Network analyses suggest that the average orthologous gene has significantly more genetic interactions than sequence orphans (that is, genes with no identifiable orthologs in other species) [42]. The $M S H$ genes are highly conserved, yet $m s h 6 \Delta$ showed an unexpectedly low percentage of negative GIs relative to all profiles in our $(953 \times 1,955)$ dataset $(4.6 \% m s h 2 \Delta ; 2.5 \%$ msh $3 \Delta$; $1.1 \% m s h 6 \Delta$ vs. $3.8 \%$ average [42]). This distinction from the general trend suggested a limited cross-talk between Msh6 and other pathways: this could be because its protein product acts exclusively in MMR, although such an interpretation is made with caution. In this study genetic interactions were revealed by the specific read-out of altered colony size on rich media. Repeating these analyses in the presence of genomic stress (for example, genotoxin-induced damage) might uncover additional, or an altered spectrum, of synthetic interactions $[61,66]$, and thus reveal more functional relationships for MutS $\alpha$.

\section{Identification of evolutionarily conserved Gls for $m s h 2 \Delta$ / $m s h 3 \Delta$ in fission/budding yeasts}

We next sought evolutionarily conserved genetic interactions (CGIs) for fission and budding yeast $m s h 2 \Delta / m s h 3 \Delta$ to identify orthologous relationships of possible utility in mammalian systems. Twenty-six candidates (25 oneto-one orthologs and the paralogous pair $\mathrm{mlp1/mlp2)}$ from the fission yeast SS/SL dataset (for example, Figure $2 \mathrm{~A}$ ) were chosen for direct study by satisfying three criteria: synthetic with both $m s h 2 \Delta$ and $m s h 3 \Delta$; identifiable $S c$ and human/mouse orthologs (or a limited group of paralogs); and non-essential in both $S c$ and hu$\mathrm{man} /$ mouse, thus increasing their potential therapeutic utility. Each mutant combination was created and examined for growth on rich-media and any additional sensitivity to genotoxins, which included 5-fluorouracil (5-FU). This agent is a commonly used chemotherapeutic for colorectal cancer, although MMR-deficient MSI-positive tumors display resistance [12,13]: thus synthetic chemosensitization in any double-mutant background would be of particular interest.

Testing these 26 candidates identified seven orthologous negative interactions, with a genotoxin-aggravating effect on the double mutant observed in most cases (Figure 3). This moderate number of CGIs for msh2/msh3 (7/25 or approximately $28 \%$ ) is consistent with recent studies interrogating the conservation of global genetic interaction trends across both yeasts [41,42]. The large-scale studies had further noted that GIs within functionally related gene pairs (such as those involved in the same pathway or process) are more highly conserved across species than those between seemingly unrelated gene pairs $[41,42]$. However the specific CGIs for $m s h 2 \Delta$ and $m s h 3 \Delta$ (Figure 3) 


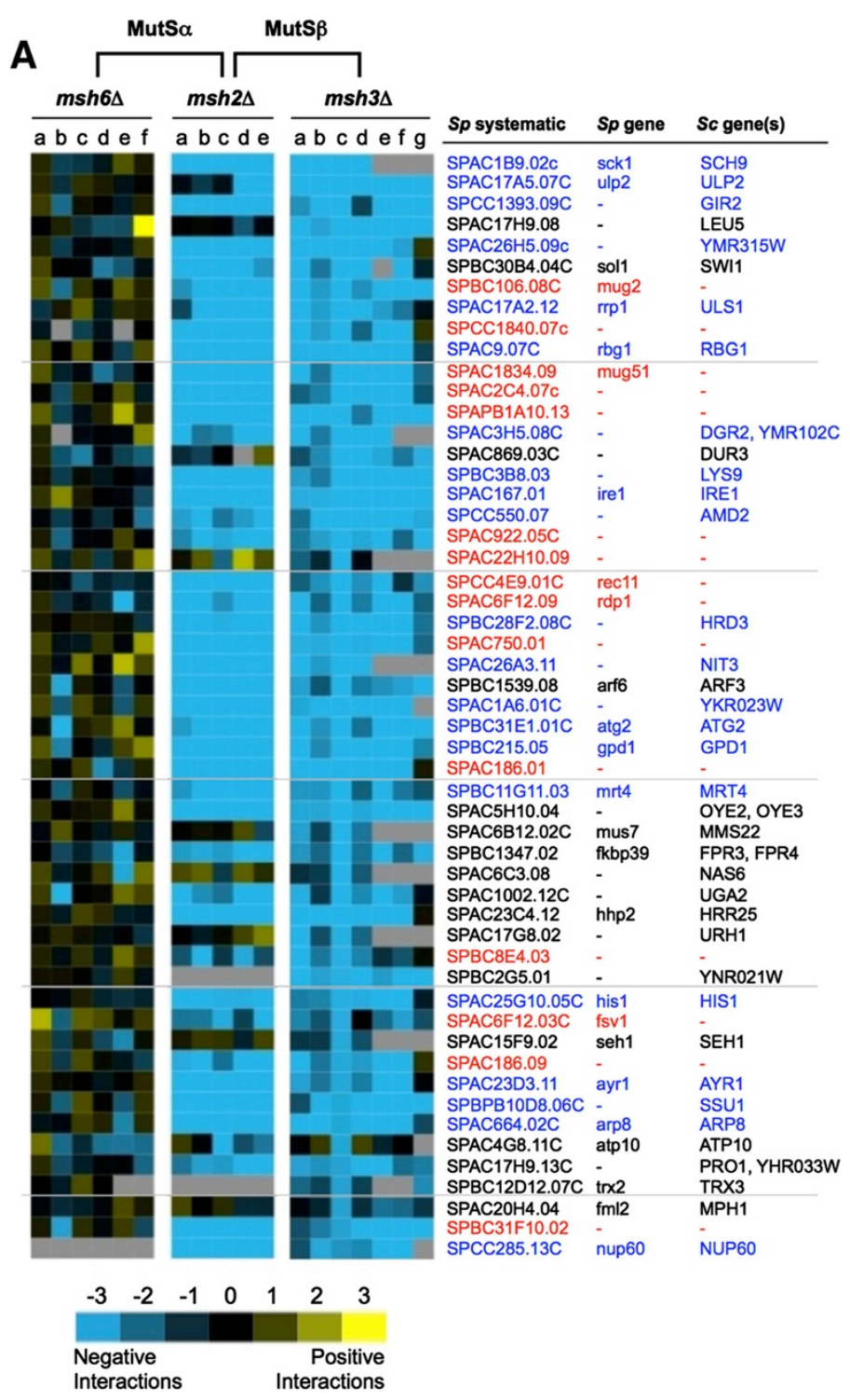

B

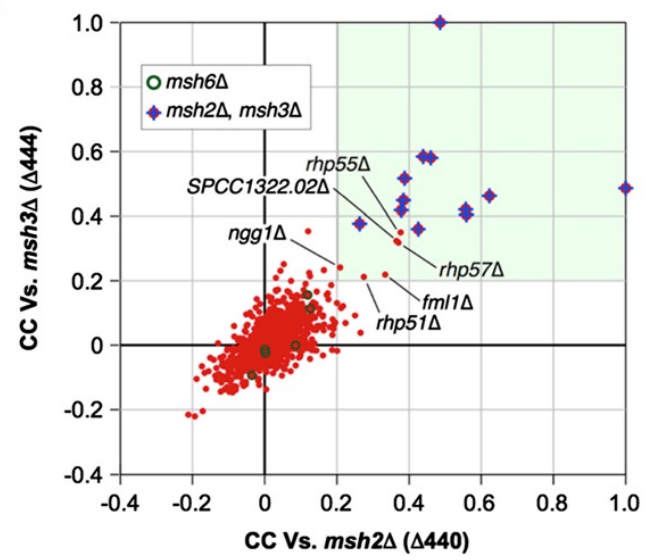

Figure $\mathbf{2}$ (See legend on next page.) 
(See figure on previous page.)

Figure 2 Genetic screening distinguishes the MutS $\beta$ complex in actively growing yeast. (A) The specific genetic interactions of fission yeast $m s h 2 \Delta$ and $m s h 3 \Delta$ are similar and distinct from $m s h 6 \Delta$. NAT-marked deletions (for example, msh2 $2 .:$ NAT) were placed in the context of 1,955 non-essential fission yeast gene deletions and relative colony size used to derive scores covering each negative $(\leq-2.5)$ genetic interaction (see Methods). Shown are a representative set of 53 genetic relationships expressed by heat map (key below) and identified by their systematic ID and standard Sp/Sc (if present) gene names. Blue, orthologous relationships also tested in budding yeast (see Figure 3). Red, Sp-specific orphans. Given the high rate of replication-errors in MMR-gene mutants [56,58], multiple queries of each deletion were screened to obtain a high confidence dataset. The independent accumulation of confounding secondary mutations may explain why the specific genetic interactors from this study are not described in the available high-throughput datasets that relied on single deletion clones [33,40,59]. (B) Distribution plot of Pearson correlation co-efficients (CCs) comparing the genetic interaction profiles of msh $2 \Delta$ and $m s h 3 \Delta$ within a $(953 \times 1,955)$ dataset. Red dots indicate the CC of each genetic screen to a specific msh $2 \Delta$ or msh3 $\Delta$ query clone: shaded area highlights screens that would be classed as significantly correlated (CC $\geq 0.2)$.

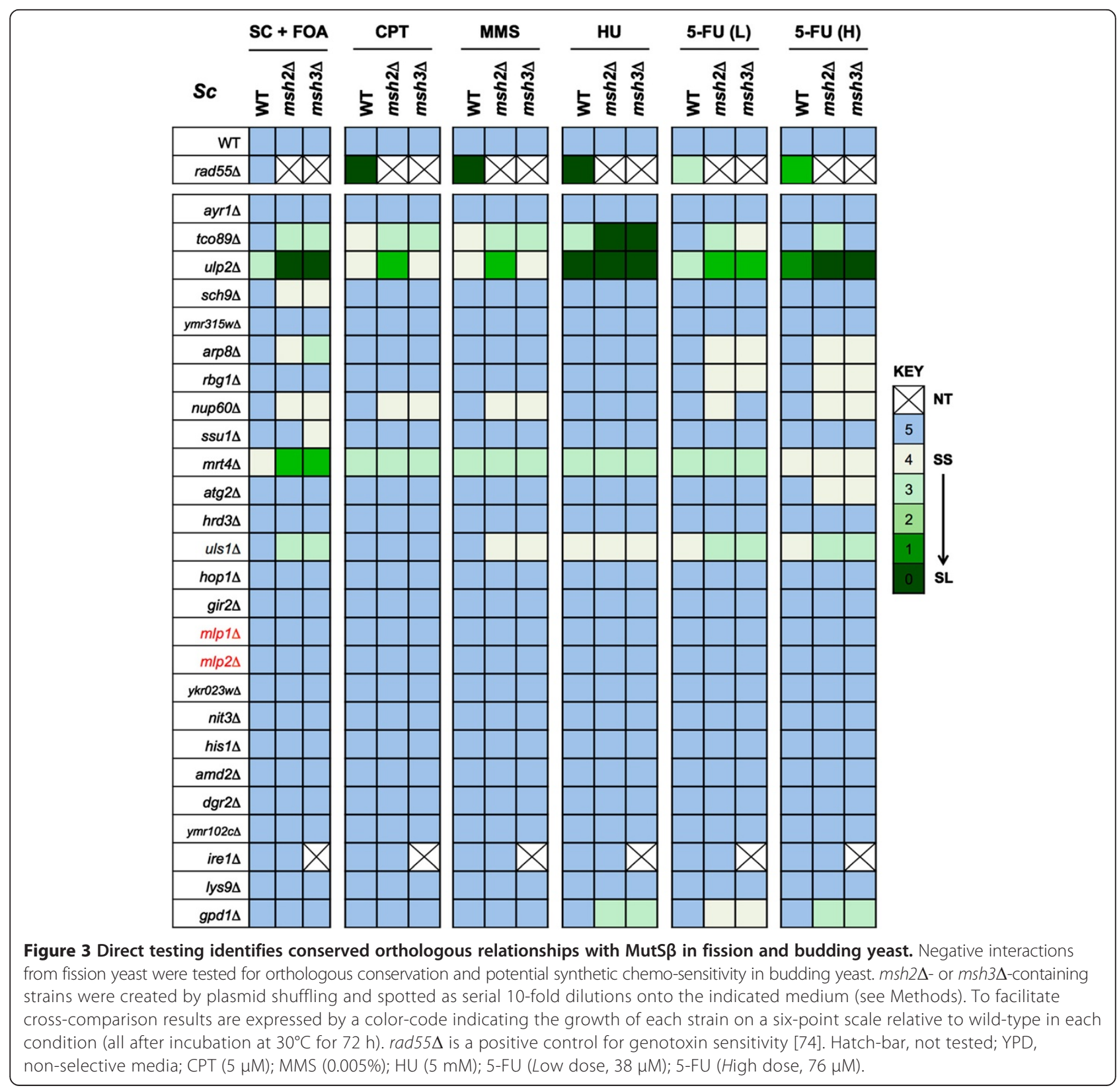


appear to be involved in quite diverse biological functions. Tco89, for example, is a subunit of the TORC1 complex that regulates growth in response to nutrient availability [67]; Sch9 is an AGC family protein kinase downstream of TORC1 mediated regulation of ribosome biogenesis, translation initiation and entry into G0 [68]; Nup60 is a nucleoporin component of the nuclear pore complex [69] and involved in gene tethering to the nuclear membrane; Arp8 is an actin-related protein and subunit of chromatin remodeling complexes [70]; and Mrt4 regulates mRNA turnover and ribosome assembly [71]. Although the molecular basis for these genetic interactions is currently unclear, their conservation across such evolutionary distance indicates functional importance and may reflect the diverse pathways involved in genome maintenance. The CGIs between $m s h 2 \Delta / m s h 3 \Delta$ and $t \cos 9 \Delta$, for example, may reflect the sensitivity of MMR-deficient colorectal cancer cells to mTOR inhibition by rapamycin [72]. Likewise the CGIs with nup60د may be linked to the role of the (Nup60/Mlp1-2) nuclear pore complex in maintaining SUMO-protease Ulp1 at the nuclear envelope to regulate the sumoylation of several proteins, including DNA repair factors [73].

The group of CGIs common to msh $2 \Delta$ and $m s h 3 \Delta$ contains two additional factors involved in protein sumoylation: Ulp2 (Sc Ulp2) and Rrp1 ( $S c$ Uls1) (Figures 2A and 3). The Ulp2 peptidase deconjugates SUMO polychains from proteins and plays a role in the recovery from checkpoint arrest induced by DNA damage or replication defects $[75,76]$. The Rrp1 ATPase regulates the proteolytic control of sumoylated substrates and the response to replication stress $[77,78]$. This cluster of CGIs strongly suggested a 'cross-talk' between MutS $\beta$ and the SUMO pathway. The $(m s h 2 \Delta / u l p 2 \Delta)$ interaction is synthetic lethal in fission yeast (Figures 2 and $4 \mathrm{~A}$ ), synthetic sick and aggravated by 5FU (a commonly used chemotherapeutic agent) in budding yeast (Figure 3). We thus chose to perform a more detailed genetic analysis of
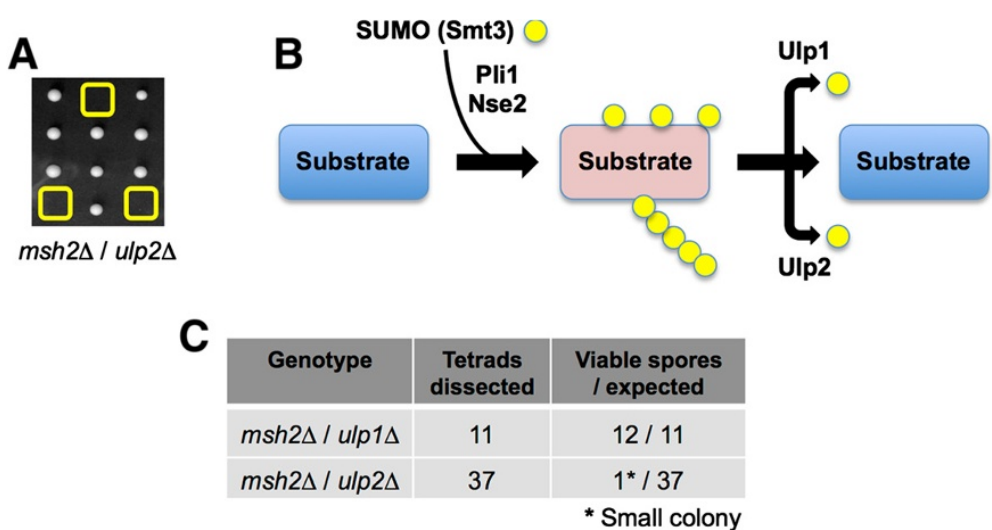

D

\begin{tabular}{|c|c|c|}
\hline Genotype & $\begin{array}{l}\text { Tetrads } \\
\text { dissected }\end{array}$ & $\begin{array}{l}\text { Viable spores } \\
\text { / expected }\end{array}$ \\
\hline smt3 $\Delta / m s h 2 \Delta /$ ulp2 $2 \Delta$ & 17 & $16 * * / 8.5$ \\
\hline 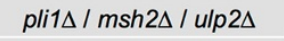 & 29 & $1 * / 14.5$ \\
\hline nse2-SA / msh2 2 / ulp2 2 & 27 & $13 / 12$ \\
\hline
\end{tabular}

E

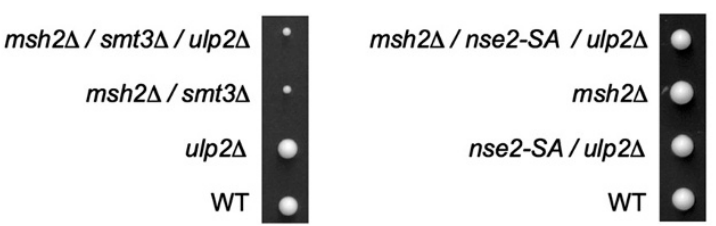

Figure 4 Increased polysumoylation is lethal in $\mathbf{m s h} 2 \Delta$ fission yeast. (A) Deletion of the Ulp2 SUMO-protease is synthetic lethal (SL) with msh $2 \Delta$. msh $2 \Delta$ and ulp2 $\Delta$ strains were mated, sporulated, tetrads dissected and genotypes determined ((ulp2 $\Delta / m s h 2 \Delta)$ is boxed). (B) Schematic depicts the sumoylation pathway. Fission yeast contains one gene encoding SUMO (Smt3), two E3-ligases (Pli1 and Nse2), and two SUMO proteases (UIp1 and Ulp2). (C) msh2 $\Delta$ is SL with ulp2 $\Delta$ but neutral with ulp $1 \Delta$. Strains were mated, sporulated, and tetrads dissected. The number of viable spores observed/expected for each genotype is indicated (see also Additional file 1: Figure S2A and B). (D, E) smt3 $\Delta$ or nse2-SA (catalytic dead), but not pli1 $\Delta$, rescue the lethality of (msh2 $\Delta /$ ulp2 $\Delta$ ). Strains were mated, sporulated, and the indicated number of tetrads dissected (see also Additional file 1: Figure S2C to E). Panel (E) depicts representative tetrads to demonstrate the growth of each mutant combination. 


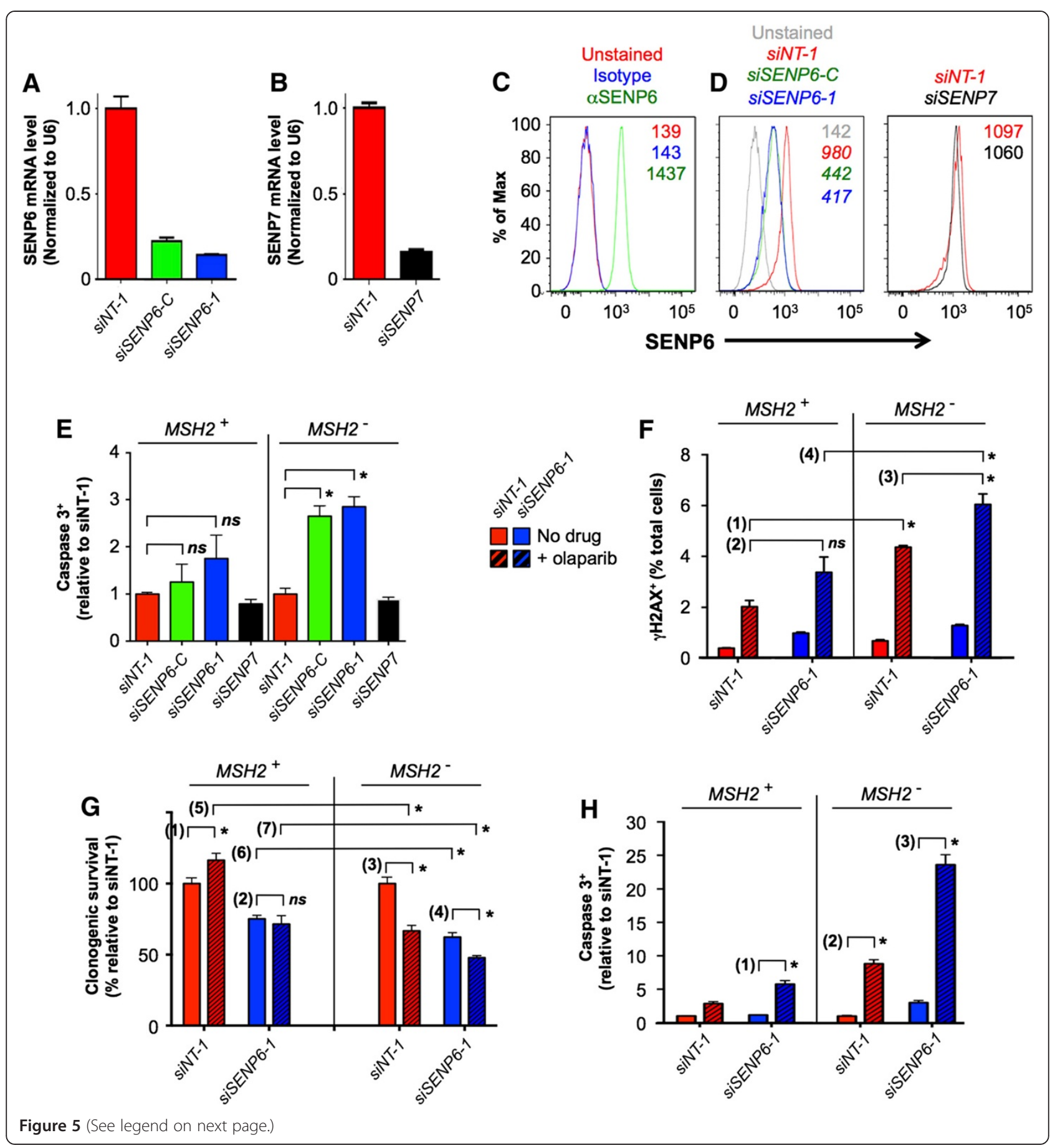




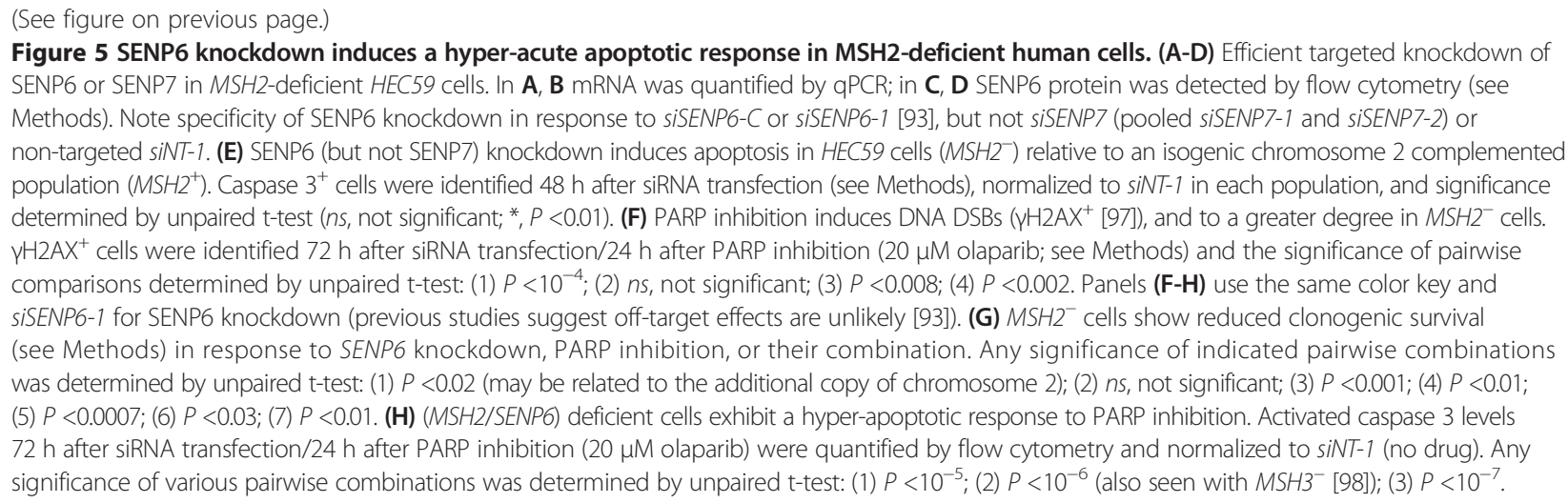

this specific CGI in fission yeast before further testing the orthologous relationship in mammalian cells.

\section{Increased polysumoylation is toxic to msh2-deficient yeast cells}

Sumoylation is a reversible post-translational modification that controls the localization, function, interaction, and stability of a large number of proteins, including many involved in transcription, replication, and the DNA damage response [79]. Indeed recent studies highlight the importance of a reversible SUMO-response to preserve genome integrity [80,81]. Fission yeast encodes one form of SUMO (Smt3 aka. Pmt3), two SUMO E3-ligases (Pli1 and Nse2), and two SUMO proteases (Ulp1 and Ulp2; Figure 4B). Pli1 catalyzes the majority of cellular sumoylation, while Nse2 targets a limited number of substrates during DNA repair $[82,83]$. For deconjugation, Ulp1 removes single SUMO modifications and is required for efficient cell cycle progression $[84,85]$. Ulp2, in contrast, edits polySUMO chains, desumoylates the majority of factors activated in response to DNA damage or DNA replication defects, and regulates the recovery from checkpoint arrest [75,76,86,87].

On direct testing the SL interaction of $(m s h 2 \Delta / u l p 2 \Delta)$ is not observed with $(m s h 2 \Delta / u l p 1 \Delta)$ (compare Figure 4A and $\mathrm{C}$ ), indicating that the accumulation of specific sumoylated substrates is toxic to fission yeast cells that also lack an Msh2-mediated repair pathway. This may be because Msh2 is absolutely required to resolve lesions that occur at increased levels in the context of $u l p 2 \Delta$ [88]. Alternatively cells lacking Msh2 might accumulate unresolved DNA damage and induce a poly-sumoylated substrate (or substrates) that cannot be metabolized in the absence of Ulp2, blocking cell cycle progression [87]. The identity of such substrates is currently unknown, though many central players in replication and recombination (for example, Rad52, PCNA, RPA) are sumoylated in response to DNA damage, and this is important for their repair function [79]. To investigate this further we tried to create triple mutants containing $m s h 2 \Delta, u l p 2 \Delta$ and a mutation in either SUMO itself $(p m t 3 \Delta)$ or one of its E3-ligases (pli1 $\Delta$, or the nse2-SA allele that lacks SUMO ligase activity but retains the essential function for $\mathrm{Nse} 2$ in chromosome maintenance [89]). Following tetrad dissection we obtained the triple mutant combinations (msh2 $\Delta / u l p 2 \Delta / p m t 3 \Delta)$ and (msh $2 \Delta / u l p 2 \Delta / n s e 2-S A)$, but not (msh2 $\Delta /$ ulp $2 \Delta / p l i 1 \Delta)$ (Figure 4D and $\mathrm{E}$ and Additional file 1: Figure S2). This clearly demonstrates that $m s h 2 \Delta$ is lethal in combination with a deletion of Ulp2, the primary protease to desumoylate DNA damage response proteins $[87,88]$, but this can be rescued by inactivating the primary ligase for sumoylation in response to DNA damage $[82,83]$.

\section{Conservation of the GI between $\mathrm{MSH} 2$ and the deSumoylation pathway in mammals}

We next sought to examine if the CGI between budding and fission yeast $m s h 2$ and $u l p 2$ predicted an orthologous relationship in human cells. Humans encode four SUMO proteins (SUMO1-4 with relatedness: SUMO1, SUMO2/3, unconjugated SUMO4) and six SUMO-specific cysteine proteases (SENPs). Of these, SENPs $1 / 2 / 3 / 5$ are most closely related to Ulp1 and specifically deconjugate single SUMO1/2/3, while SENPs 6/7 resemble Ulp2 and edit polysumo chains with a clear preference for SUMO2/3 [90-92]. A limited literature discriminates the distinct roles of mammalian SENP6 and SENP7 [93-95]. However both are expressed in a variety of tissues including the colonic epithelium [90] and thus might be active in MMR-deficient colorectal cancer cells.

To investigate any relationship between human MSH2, SENP6, and SENP7 we used siRNA to efficiently knockdown each SUMO protease in HEC59 cells (an Msh2-deficient endometrial cancer line) and their isogenic chromosome 2-complemented MSH2 proficient counterparts (Figure 5A to D). SENP6 knockdown resulted in significantly increased apoptosis in MSH2deficient relative to $\mathrm{MSH} 2$-proficient cells (Figure 5E), 
reproducing the negative genetic interaction identified in budding and fission yeasts (Figures $2 \mathrm{~A}$ and 3 ). Interestingly SENP7 knockdown had no effect (Figure 5E). This SUMO protease was recently shown to interact with chromatin remodelers and contribute to chromatin relaxation during DNA repair by homologous recombination [94-96]. However our results indicate that the effect of SENP7 knockdown on recombinational repair does not lead to increased apoptosis in $\mathrm{MSH} 2$-deficient cells.

Human SENP6 maintains the hypo-sumoylation of RPA70, and thus regulates homologous recombinationmediated repair during S-phase [93]. This finding allied with our results in yeast may imply that the conserved synthetic interaction between MSH2/msh2 and SENP6/ ulp2 is due to the combined loss of MutS $\beta$ - and RPAmediated DNA DSB repair. Consistent with this notion, the addition of Olaparib (a PARP inhibitor that induces the accumulation of ssDNA breaks that ultimately result in DSBs during replication [99-101]) rendered a significantly greater number of $\gamma \mathrm{H}_{2} \mathrm{AX}^{+}$cells in the (MSH2/SENP6) deficient population versus singly-deficient controls (Figure 5F). This is accompanied by the reduced clonogenic survival of $\mathrm{MSH}^{-}$cells in response to SENP6 knockdown, olaparib treatment, or their combination (Figure 5F). In isolation this synthetic interaction provides no direct mechanistic insight, but further analyses showed that the (MSH2/SENP6) deficient population also displayed a hyper-acute apoptotic response to olaparib (Figure $5 \mathrm{H})$. It appears likely that (MSH2/SENP6) deficient cells are incapable of resolving the genomic lesions induced by PARP-inhibition, with apoptosis becoming a preferred response. Olaparib is currently in phase II clinical trials for the treatment of $B R C A 1 / 2$ dependent breast and ovarian cancers [102-104]. Our findings suggest that it may also enhance the efficacy of strategies that target components of DSB repair pathways in MSH2-deficient tumors.

\section{Conclusions}

This study describes the identification of conserved genetic interactions between the MutS $\beta$ subunits and orthologous genes encoding diverse biological functions in two evolutionarily distant yeast species. It further demonstrates that unexpected genetic relationships could be exploited to treat loss-of-function disorders. In the specific example presented, the synthetic interaction of (MSH2/ SENP6) deficiency enhanced by PARP inhibitors indicates that a significant proportion of MMR-deficient cancers could be targeted via their loss of function in MutS $\beta$ mediated recombinatorial, rather than mismatch, repair [10] (Figure 1A). Ongoing studies have established the central role of reversible sumoylation in an efficient DNA damage response, suggesting that the SUMO pathway might contain novel druggable targets for anticancer therapeutics $[79,105]$. In this work we suggest that targeting specific SUMO proteases may be highly effective in the treatment of MMR-deficient cancers. The recent development of SENP6-specific small molecule inhibitors [106] could prove invaluable for further experiments in this regard.

\section{Additional file}

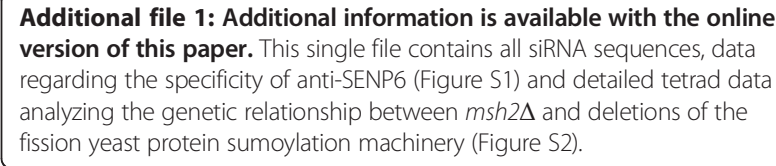

\section{Abbreviations}

5-FU: 5-fluorouracil; CGI: Conserved genetic interaction; CRC: Colorectal cancer; DSB: Double-strand break; GI: Genetic interaction; HNPCC/LS: Hereditary nonpolyposis colorectal cancer/Lynch syndrome; HR: Homologous recombination; MMR: DNA mismatch repair; MSH: MutS homolog; MSI: Microsatellite instability; RNAi: RNA interference; Sc: Saccharomyces cerevisiae; Sp: Schizosaccharomyces pombe; SS/SL: Synthetic sick/synthetic lethal.

\section{Competing interests}

The authors declare that they have no competing interests.

\section{Authors' contributions}

ET, JAK, NJK, DP, MCK, and WE designed the experiments; ET, JAK, SS, HSK, $\mathrm{CJR}$, and AR performed the research; ET, JAK, SS, CJR, MS, NJK, DP, MCK, and WE analyzed the data; ET, MCK, and WE wrote the paper. All authors read and approved the final manuscript.

\section{Acknowledgements}

CJR is supported by ICON plc and the UCD Newman Fellowship Program. This work was supported by the NIH (ES019966, CA76329 and CA93484) and an NCl Cancer Center Support grant to Albert Einstein College of Medicine (CA013330)

\section{Author details}

'Department of Cell Biology, Albert Einstein College of Medicine, New York, USA. ${ }^{2}$ Department of Microbiology \& Immunology, Albert Einstein College of Medicine, New York, USA. ${ }^{3}$ Department of Cellular \& Molecular Pharmacology, UCSF, San Francisco, USA. ${ }^{4}$ California Institute for Quantitative Biosciences, San Francisco, USA. ${ }^{5}$ School of Medicine and Medical Science, University College Dublin, Dublin, Ireland. ${ }^{6}$. David Gladstone Institutes, San Francisco, USA.

Received: 31 December 2013 Accepted: 28 August 2014

Published online: 17 September 2014

\section{References}

1. Rustgi AK: The genetics of hereditary colon cancer. Genes Dev 2007, 21:2525-2538

2. Hampel $H$, Frankel WL, Martin E, Arnold M, Khanduja K, Kuebler $P$, Nakagawa H, Sotamaa K, Prior TW, Westman J, Panescu J, Fix D, Lockman J, Comeras I, de la Chapelle A: Screening for the Lynch syndrome (hereditary nonpolyposis colorectal cancer). N Engl J Med 2005, 352:1851-1860.

3. Iyer RR, Pluciennik A, Burdett V, Modrich PL: DNA mismatch repair: functions and mechanisms. Chem Rev 2006, 106:302-323.

4. Kunkel TA, Erie DA: DNA mismatch repair. Annu Rev Plant Physiol Plant Mol Biol 2005, 74:681-710

5. Harrington JM, Kolodner RD: Saccharomyces cerevisiae Msh2-Msh3 acts in repair of base-base mispairs. Mol Cell Biol 2007, 27:6546-6554.

6. Acharya S, Wilson T, Gradia S, Kane MF, Guerrette S, Marsischky GT, Kolodner $\mathrm{R}$, Fishel R: hMSH2 forms specific mispair-binding complexes with hMSH3 and hMSH6. Proc Natl Acad Sci U S A 1996, 93:13629-13634. 
7. Srivatsan A, Bowen N, Kolodner RD: Mispair-specific recruitment of the Mlh1-Pms1 complex identifies repair substrates of the Saccharomyces cerevisiae Msh2-Msh3 complex. J Biol Chem 2014, 289:9352-9364.

8. Palombo F, laccarino I, Nakajima E, Ikejima M, Shimada T, Jiricny J: hMutSbeta, a heterodimer of hMSH2 and hMSH3, binds to insertion/ deletion loops in DNA. Curr Biol 1996, 6:1181-1184.

9. Umar A, Risinger JI, Glaab WE, Tindall KR, Barrett JC, Kunkel TA: Functional overlap in mismatch repair by human MSH3 and MSH6. Genetics 1998, 148:1637-1646.

10. van Oers JM, Edwards Y, Chahwan R, Zhang W, Smith C, Pechuan X, Schaetzlein S, Jin B, Wang Y, Bergman A, Scharff MD, Edelmann W: The Mut $S \beta$ complex is a modulator of $p 53$-driven tumorigenesis through its functions in both DNA double-strand break repair and mismatch repair Oncogene 2013, 33:3939-3946.

11. Sugawara N, Pâques F, Colaiácovo M, Haber JE: Role of Saccharomyces cerevisiae Msh2 and Msh3 repair proteins in double-strand break-induced recombination. Proc Natl Acad Sci U S A 1997, 94:9214-9219.

12. Fink D, Aebi $S$, Howell SB: The role of DNA mismatch repair in drug resistance. Clin Cancer Res 1998, 4:1-6.

13. Jover R, Zapater P, Castells A, Llor X, Andreu M, Cubiella J, Balaguer F, Sempere L, Xicola RM, Bujanda L, Reñé JM, Clofent J, Bessa X, Morillas JD, Nicolás-Pérez D, Pons E, Payá A, Alenda C, Gastrointestinal Oncology Group of the Spanish Gastroenterological Association: The efficacy of adjuvant chemotherapy with 5-fluorouracil in colorectal cancer depends on the mismatch repair status. Eur J Cancer 2009, 45:365-373.

14. Mao G, Yuan F, Absher K, Jennings CD, Howard DS, Jordan CT, Gu L: Preferential loss of mismatch repair function in refractory and relapsed acute myeloid leukemia: potential contribution to $\mathrm{AML}$ progression. Cell Res 2008, 18:281-289.

15. Offman J, Opelz G, Doehler B, Cummins D, Halil O, Banner NR, Burke MM, Sullivan D, Macpherson P, Karran P: Defective DNA mismatch repair in acute myeloid leukemia/myelodysplastic syndrome after organ transplantation. Blood 2004, 104:822-828.

16. Bignami M, Casorelli I, Karran P: Mismatch repair and response to DNA-damaging antitumour therapies. Eur J Cancer 2003, 39:2142-2149.

17. Kaelin WG Jr: The concept of synthetic lethality in the context of anti-cancer therapy. Nat Rev Cancer 2005, 5:689-698.

18. Chan DA, Giaccia AJ: Harnessing synthetic lethal interactions in anticancer drug discovery. Nat Rev Drug Discov 2011, 10:351-364.

19. Farmer H, McCabe N, Lord CJ, Tutt AN, Johnson DA, Richardson TB, Santarosa M, Dillon KJ, Hickson I, Knights C, Martin NM, Jackson SP, Smith GC, Ashworth A: Targeting the DNA repair defect in BRCA mutant cells as a therapeutic strategy. Nature 2005, 434:917-921.

20. Hay T, Matthews JR, Pietzka L, Lau A, Cranston A, Nygren AO, Douglas-Jones A, Smith GC, Martin NM, O'Connor M, Clarke AR: Poly(ADP-ribose) polymerase-1 inhibitor treatment regresses autochthonous Brca2/p53-mutant mammary tumors in vivo and delays tumor relapse in combination with carboplatin. Cancer Res 2009, 69:3850-3855.

21. Roguev A, Talbot D, Negri GL, Shales M, Cagney G, Bandyopadhyay S, Panning B, Krogan NJ: Quantitative genetic-interaction mapping in mammalian cells. Nat Methods 2013, 10:432-437.

22. Iorns E, Lord CJ, Turner N, Ashworth A: Utilizing RNA interference to enhance cancer drug discovery. Nat Rev Drug Discov 2007, 6:556-568.

23. Luo J, Emanuele MJ, Li D, Creighton CJ, Schlabach MR, Westbrook TF, Wong KK, Elledge SJ: A genome-wide RNAi screen identifies multiple synthetic lethal interactions with the Ras oncogene. Cell 2009, 137:835-848.

24. Kim YW, Liu T, Koul D, Tiao N, Feroze AH, Wang J, Powis G, Yung WK: Identification of novel synergistic targets for rational drug combinations with $\mathrm{PI} 3$ kinase inhibitors using siRNA synthetic lethality screening against GBM. Neuro Oncol 2011, 13:367-375

25. Martin SA, McCabe N, Mullarkey M, Cummins R, Burgess DJ, Nakabeppu Y, Oka S, Kay E, Lord CJ, Ashworth A: DNA polymerases as potential therapeutic targets for cancers deficient in the DNA mismatch repair proteins MSH2 or MLH1. Cancer Cell 2010, 17:235-248.

26. Martin SA, McCarthy A, Barber $\sqcup$, Burgess DJ, Parry S, Lord CJ, Ashworth A: Methotrexate induces oxidative DNA damage and is selectively lethal to tumour cells with defects in the DNA mismatch repair gene MSH2. EMBO Mol Med 2009, 1:323-337.

27. Loeb LA, Monnat RJ Jr: DNA polymerases and human disease. Nat Rev Genet 2008, 9:594-604.
28. Cabelof DC, Ikeno Y, Nyska A, Busuttil RA, Anyangwe N, Vijg J, Matherly LH, Tucker JD, Wilson SH, Richardson A, Heydari AR: Haploinsufficiency in DNA polymerase beta increases cancer risk with age and alters mortality rate. Cancer Res 2006, 66:7460-7465.

29. Boone C, Bussey H, Andrews BJ: Exploring genetic interactions and networks with yeast. Nat Rev Genet 2007, 8:437-449.

30. McGary KL, Park TJ, Woods JO, Cha HJ, Wallingford JB, Marcotte EM: Systematic discovery of nonobvious human disease models through orthologous phenotypes. Proc Natl Acad Sci U S A 2010, 107:6544-6549.

31. Sipiczki M: Where does fission yeast sit on the tree of life? Genome Biol 2000, 1:reviews1011.1-reviews1011.4.

32. O'Brien SJ, Menotti-Raymond M, Murphy WJ, Nash WG, Wienberg J, Stanyon R, Copeland NJ, Jenkins NA, Womack JE, Graves JA: The promise of comparative genomics in mammals. Science 1999, 286:458-481.

33. Dixon SJ, Fedyshyn Y, Koh JL, Prasad TS, Chahwan C, Chua G, Toufighi K, Baryshnikova A, Hayles J, Hoe KL, Kim DU, Park HO, Myers CL, Pandey A, Durocher D, Andrews BJ, Boone C: Significant conservation of synthetic lethal genetic interaction networks between distantly related eukaryotes. Proc Natl Acad Sci U S A 2008, 105:16653-16658.

34. Roguev A, Bandyopadhyay S, Zofall M, Zhang K, Fischer T, Collins SR, Qu H, Shales M, Park HO, Hayles J, Hoe KL, Kim DU, Ideker T, Grewal SI, Weissman JS, Krogan NJ: Conservation and rewiring of functional modules revealed by an epistasis map (E-MAP) in fission yeast. science 2008, 322:405-410.

35. Kim DU, Hayles J, Kim D, Wood V, Park HO, Won M, Yoo HS, Duhig T, Nam M, Palmer G, Han S, Jeffery L, Baek ST, Lee H, Shim YS, Lee M, Kim L, Heo KS, Noh EJ, Lee AR, Jang YJ, Chung KS, Choi SJ, Park JY, Park Y, Kim HM, Park SK, Park HJ, Kang EJ, Kim HB, et al: Analysis of a genome-wide set of gene deletions in the fission yeast Schizosaccharomyces pombe. Nat Biotechnol 2010, 28:617-623.

36. Shevchenko A, Roguev A, Schaft D, Buchanan L, Habermann B, Sakalar C, Thomas H, Krogan NJ, Shevchenko A, Stewart AF: Chromatin Central: towards the comparative proteome by accurate mapping of the yeast proteomic environment. Genome Biol 2008, 9:R167.

37. Bao Y, Shen X: SnapShot: chromatin remodeling complexes. Cell 2007, 129:632.

38. Tong AH, Lesage $G$, Bader GD, Ding H, Xu H, Xin X, Young J, Berriz GF, Brost RL, Chang M, Chen Y, Cheng X, Chua G, Friesen H, Goldberg DS, Haynes J, Humphries C, He G, Hussein S, Ke L, Krogan N, Li Z, Levinson JN, Lu H, Ménard P, Munyana C, Parsons AB, Ryan O, Tonikian R, Roberts T, et al: Global mapping of the yeast genetic interaction network. Science 2004, 303:808-813.

39. Giaever G, Chu AM, Ni L, Connelly C, Riles L, Veronneau S, Dow S, Lucau-Danila A, Anderson K, André B, Arkin AP, Astromoff A, El-Bakkoury M, Bangham R, Benito R, Brachat S, Campanaro S, Curtiss M, Davis K, Deutschbauer A, Entian KD, Flaherty P, Foury F, Garfinkel DJ, Gerstein M, Gotte D, Güldener U, Hegemann JH, Hempel S, Herman Z, et al: Functional profiling of the Saccharomyces cerevisiae genome. Nature 2002, 418:387-391.

40. Costanzo M, Baryshnikova A, Bellay J, Kim Y, Spear ED, Sevier CS, Ding H, Koh JL, Toufighi K, Mostafavi S, Prinz J, St Onge RP, VanderSluis B, Makhnevych T, Vizeacoumar FJ, Alizadeh S, Bahr S, Brost RL, Chen Y, Cokol M, Deshpande R, Li Z, Lin ZY, Liang W, Marback M, Paw J, San Luis BJ, Shuteriqi $\mathrm{E}$, Tong $\mathrm{AH}$, van Dyk $\mathrm{N}$, et al: The genetic landscape of a cell. Science 2010, 327:425-431.

41. Frost A, Elgort MG, Brandman O, Ives C, Collins SR, Miller-Vedam L, Weibezahn J, Hein MY, Poser I, Mann M, Hyman AA, Weissman JS: Functional repurposing revealed by comparing $S$. pombe and S. cerevisiae genetic interactions. Cell 2012, 149:1339-1352

42. Ryan CJ, Roguev A, Patrick K, Xu J, Jahari H, Tong Z, Beltrao P, Shales M, Qu H, Collins SR, Kliegman Jl, Jiang L, Kuo D, Tosti E, Kim HS, Edelmann W, Keogh MC, Greene D, Tang C, Cunningham P, Shokat KM, Cagney G, Svensson JP, Guthrie C, Espenshade PJ, Ideker T, Krogan NJ: Hierarchical modularity and the evolution of genetic interactomes across species. Mol Cell 2012, 46:691-704.

43. Modrich PL: Mechanisms in eukaryotic mismatch repair. J Biol Chem 2006, 281:30305-30309.

44. Keogh M-C, Cho E-J, Podolny V, Buratowski S: Kin28 is found within TFIIH and a Kin28-Ccl1-Tfb3 trimer complex with differential sensitivities to T-loop phosphorylation. Mol Cell Biol 2002, 22:1288-1297.

45. Janke C, Magiera MM, Rathfelder N, Taxis C, Reber S, Maekawa H, Moreno-Borchart A, Doenges G, Schwob E, Schiebel E, Knop M: A 
versatile toolbox for PCR-based tagging of yeast genes: new fluorescent proteins, more markers and promoter-substitution cassettes. Yeast 2004, 21:947-962

46. Kim H-S, Vanoosthuyse V, Fillingham J, Roguev A, Watt S, Kislinger T, Treyer A, Carpenter LR, Bennett CS, Emili A, Greenblatt JF, Hardwick KG, Krogan NJ, Bähler J, Keogh MC: An acetylated form of histone H2A.Z regulates chromosome architecture in Schizosaccharomyces pombe. Nat Struct Mol Biol 2009, 16:1286-1293.

47. Roguev A, Wiren M, Weissman JS, Krogan NJ: High-throughput genetic interaction mapping in the fission yeast Schizosaccharomyces pombe. Nat Methods 2007, 4:861-866.

48. Li GM: Mechanisms and functions of DNA mismatch repair. Cell Res 2008, 18:85-98.

49. Watanabe $Y$, Haugen-Strano A, Umar A, Yamada K, Hemmi H, Kikuchi Y, Takano S, Shibata Y, Barrett JC, Kunkel TA, Koi M: Complementation of an hMSH2 defect in human colorectal carcinoma cells by human chromosome 2 transfer. Mol Carcinog 2000, 29:37-49.

50. Palliser D, Chowdhury D, Wang QY, Lee SJ, Bronson RT, Knipe DM, Lieberman J: An siRNA-based microbicide protects mice from lethal herpes simplex virus 2 infection. Nature 2006, 429:89-94.

51. Edelmann W, Umar A, Yang K, Heyer J, Kucherlapati M, Lia M, Kneitz B, Avdievich E, Fan K, Wong E, Crouse G, Kunkel T, Lipkin M, Kolodner RD, Kucherlapati R: The DNA mismatch repair genes Msh3 and Msh6 cooperate in intestinal tumor suppression. Cancer Res 2000, 60:803-807.

52. Kim TM, Laird PW, Park PJ: The landscape of microsatellite instability in colorectal and endometrial cancer genomes. Cell 2013, 155:858-868.

53. Plaschke J, Kruger S, Jeske B, Theissig F, Kreuz FR, Pistorius S, Saeger HD laccarino I, Marra G, Schackert HK: Loss of MSH3 protein expression is frequent in MLH1-deficient colorectal cancer and is associated with disease progression. Cancer Res 2004, 64:864-870.

54. Poulogiannis G, Frayling IM, Arends MJ: DNA mismatch repair deficiency in sporadic colorectal cancer and Lynch syndrome. Histopathology 2010, 56:167-179.

55. Marischky GT, Foliso N, Kane MF, Kolodner R: Redundancy of Saccharomyces cerevisiae MSH3 and MSH6 in MSH2-dependent mismatch repair. Genes Dev 1996, 10:407-420.

56. Mansour AA, Tornier C, Lehmann E, Darmon M, Fleck O: Control of GT repeat stability in Schizosaccharomyces pombe by mismatch repair factors. Genetics 2001, 158:77-85.

57. Fishel R, Lescoe MK, Rao MR, Copeland NG, Jenkins NA, Garber J, Kane M, Kolodner R: The human mutator gene homolog MSH2 and its association with hereditary nonpolyposis colon cancer. Cell 1993, 75:1027-1038.

58. Rudolph C, Kunz C, Parisi S, Lehmann E, Hartsuiker E, Fartmann B, Kramer W, Kohli J, Fleck O: The msh2 gene of Schizosaccharomyces pombe is involved in mismatch repair, mating-type switching, and meiotic chromosome organization. Mol Cell Biol 1999, 19:241-250.

59. Collins SR, Miller KM, Maas NL, Roguev A, Fillingham J, Chu CS, Schuldiner M, Gebbia M, Recht J, Shales M, Ding H, Xu H, Han J, Ingvarsdottir K, Cheng B, Andrews B, Boone C, Berger SL, Hieter P, Zhang Z, Brown GW, Ingles CJ, Emili A, Allis CD, Toczyski DP, Weissman JS, Greenblatt JF, Krogan NJ: Functional dissection of protein complexes involved in yeast chromosome biology using a genetic interaction map. Nature 2007, 446:806-810.

60. Schuldiner M, Collins SR, Weissman JS, Krogan NJ: Quantitative genetic analysis in Saccharomyces cerevisiae using epistatic miniarray profiles (E-MAPs) and its application to chromatin functions. Methods 2006, 40:344-352.

61. Bandyopadhyay S, Mehta M, Kuo D, Sung M-K, Chuang R, Jaehnig EJ, Bodenmiller B, Licon K, Copeland W, Shales M, Fiedler D, Dutkowski J, Guénolé A, van Attikum H, Shokat KM, Kolodner RD, Huh WK, Aebersold R, Keogh MC, Krogan NJ, Ideker T: Rewiring of genetic networks in response to DNA damage. Science 2010, 330:1385-1389.

62. Raji H, Hartsuiker E: Double-strand break repair and homologous recombination in Schizosaccharomyces pombe. Yeast 2006, 23:963-976.

63. Sun W, Nandi S, Osman F, Ahn JS, Jakovleska J, Lorenz A, Whitby MC: The FANCM ortholog Fml1 promotes recombination at stalled replication forks and limits crossing over during DNA double-strand break repair. Mol Cell 2008, 32:118-128.

64. Saparbaev M, Prakash L, Prakash S: Requirement of mismatch repair genes MSH2 and MSH3 in the RAD1-RAD10 pathway of mitotic recombination in Saccharomyces cerevisiae. Genetics 1996, 142:727-736.
65. Nicholson A, Fabbri RM, Reeves JW, Crouse GF: The effects of mismatch repair and RAD1 genes on interchromosomal crossover recombination in Saccharomyces cerevisiae. Genetics 2006, 173:647-659.

66. Guénolé A, Srivas R, Vreeken K, Wang ZZ, Wang S, Krogan NJ, Ideker T, van Attikum $\mathrm{H}$ : Dissection of DNA damage responses using multiconditional genetic interaction maps. Mol Cell 2013, 49:346-358.

67. Reinke A, Anderson S, McCaffery JM, Yates J 3rd, Aronova S, Chu S, Fairclough S, Iverson C, Wedaman KP, Powers T: TOR complex 1 includes a novel component, Tco89p (YPL180w), and cooperates with Ssd1p to maintain cellular integrity in Saccharomyces cerevisiae. J Biol Chem 2004, 279:14752-14762.

68. Toda T, Cameron S, Sass P, Wigler M: SCH9, a gene of Saccharomyces cerevisiae that encodes a protein distinct from, but functionally and structurally related to, cAMP-dependent protein kinase catalytic subunits. Genes Dev 1988, 2:517-527.

69. Rout MP, Aitchison JD, Suprapto A, Hjertaas K, Zhao Y, Chait BT: The yeast nuclear pore complex: composition, architecture, and transport mechanism. J Cell Biol 2000, 148:635-651.

70. Saravanan M, Wuerges J, Bose D, McCormack EA, Cook NJ, Zhang X, Wigley DB: Interactions between the nucleosome histone core and Arp8 in the INO80 chromatin remodeling complex. Proc Natl Acad Sci U S A 2012, 109:20883-20888.

71. Harnpicharnchai P, Jakovljevic J, Horsey E, Miles T, Roman J, Rout M, Meagher D, Imai B, Guo Y, Brame CJ, Shabanowitz J, Hunt DF, Woolford JL $\mathrm{Jr}$ : Composition and functional characterization of yeast $66 \mathrm{~S}$ ribosome assembly intermediates. Mol Cell 2001, 8:505-515.

72. Vilar E, Mukherjee B, Kuick R, Raskin L, Misek DE, Taylor JM, Giordano TJ, Hanash SM, Fearon ER, Rennert G, Gruber SB: Gene expression patterns in mismatch repair-deficient colorectal cancers highlight the potential therapeutic role of inhibitors of the phosphatidylinositol 3-kinase-AKT-mammalian target of rapamycin pathway. Clin Cancer Res 2009, 15:2829-2839.

73. Palancade B, Liu X, Garcia-Rubio M, Aguilera A, Zhao X, Doye V: Nucleoporins prevent DNA damage accumulation by modulating Ulp1-dependent sumoylation processes. Mol Biol Cell 2007, 18:2912-2923.

74. Parsons AB, Brost RL, Ding H, Li Z, Zhang CL, Sheikh B, Brown GW, Kane PM, Hughes TR, Boone C: Integration of chemical-genetic and genetic interaction data links bioactive compounds to cellular target pathways. Nat Biotechnol 2004, 22:62-69.

75. Li SJ, Hochstrasser M: The yeast ULP2 (SMT4) gene encodes a novel protease specific for the ubiquitin-like Smt3 protein. Mol Cell Biol 2000, 20:2367-2377.

76. Bylebyl GR, Belichenko I, Johnson ES: The SUMO isopeptidase UIp2 prevents accumulation of SUMO chains in yeast. J Biol Chem 2003, 278:44113-44120.

77. Uzunova K, Gottsche K, Miteva M, Weisshaar SR, Glanemann C, Schnellhardt M, Niessen M, Scheel H, Hofmann K, Johnson ES, Praefcke GJ, Dohmen RJ: Ubiquitin-dependent proteolytic control of SUMO conjugates. J Biol Chem 2007, 282:34167-34175.

78. Dziadkowiec D, Petters E, Dyjankiewicz A, Karpiński P, Garcia V, Watson A Carr AM: The role of novel genes $\operatorname{rrp1}(+)$ and $\operatorname{rrp2}(+)$ in the repair of DNA damage in Schizosaccharomyces pombe. DNA Repair (Amst) 2009, 8:627-636.

79. Jackson SP, Durocher D: Regulation of DNA Damage Responses by Ubiquitin and SUMO. Mol Cell 2013, 49:795-807.

80. Cremona CA, Sarangi P, Yang Y, Hang LE, Rahman S, Zhao X: Extensive DNA damage-induced sumoylation contributes to replication and repair and acts in addition to the mec1 checkpoint. Mol Cell 2012, 45:422-432.

81. Nagai S, Davoodi N, Gasser SM: Nuclear organization in genome stability: SUMO connections. Cell Res 2011, 21:474-485.

82. Watts FZ, Skilton A, Ho JC, Boyd LK, Trickey MA, Gardner L, Ogi FX, Outwin EA: The role of Schizosaccharomyces pombe SUMO ligases in genome stability. Biochem Soc Trans 2007, 35:1379-1384.

83. Stephan AK, Kliszczak M, Morrison CG: The Nse2/Mms21 SUMO ligase of the Smc5/6 complex in the maintenance of genome stability. FEBS Lett 2011, 585:2907-2913.

84. Elmore ZC, Donaher M, Matson BC, Murphy H, Westerbeck JW, Kerscher O: Sumo-dependent substrate targeting of the SUMO protease Ulp1. BMC Biol 2011, 9:74

85. Soustelle C, Vernis L, Fréon K, Reynaud-Angelin A, Chanet R, Fabre F, Heude M: A new Saccharomyces cerevisiae strain with a mutant Smt3-deconjugating Ulp1 protein is affected in DNA replication and requires Srs2 and homologous recombination for its viability. Mol Cell Biol 2004, 24:5130-5143. 
86. Bekes M, Prudden J, Srikumar T, Raught B, Boddy MN, Salvesen GS: The dynamics and mechanism of SUMO chain deconjugation by SUMO-specific proteases. J Biol Chem 2011, 286:10238-10247.

87. Felberbaum R, Hochstrasser M: Ulp2 and the DNA damage response: desumoylation enables safe passage through mitosis. Cell Cycle 2008, 7:52-56.

88. Lee MT, Bakir AA, Nguyen KN, Bachant J: The SUMO isopeptidase UIp2p is required to prevent recombination-induced chromosome segregation lethality following DNA replication stress. PLOS Genet 2011, 7:e1001355.

89. McDonald WH, Pavlova Y, Yates JR 3rd, Boddy MN: Novel essential DNA repair proteins $\mathrm{Nse} 1$ and $\mathrm{Nse} 2$ are subunits of the fission yeast Smc5-Smc6 complex. J Biol Chem 2003, 278:45460-45467.

90. Mukhopadhyay D, Dasso M: Modification in reverse: the SUMO proteases. Trends Biochem Sci 2007, 32:286-295.

91. Kolli N, Mikolajczyk J, Drag M, Mukhopadhyay D, Moffatt N, Dasso M, Salvesen G, Wilkinson KD: Distribution and paralogue specificity of mammalian deSUMOylating enzymes. Biochem J 2010, 430:335-344.

92. Alegre $\mathrm{KO}$, Reverter $\mathrm{D}$ : Swapping small ubiquitin-like modifier (SUMO) isoform specificity of SUMO proteases SENP6 and SENP7. J Biol Chem 2011, 286:36142-36151.

93. Dou H, Huang C, Singh M, Carpenter PB, Yeh ET: Regulation of DNA repair through deSUMOylation and SUMOylation of replication protein $\mathrm{A}$ complex. Mol Cell 2010, 39:333-345.

94. Maison C, Romeo K, Bailly D, Dubarry M, Quivy JP, Almouzni G: The SUMO protease SENP7 is a critical component to ensure HP1 enrichment at pericentric heterochromatin. Nat Struct Mol Biol 2012, 19:458-460.

95. Bawa-Khalfe T, Lu LS, Zuo Y, Huang C, Dere R, Lin FM, Yeh ET: Differential expression of SUMO-specific protease 7 variants regulates epithelialmesenchymal transition. Proc Natl Acad Sci U S A 2012, 109:17466-17471.

96. Garvin AJ, Densham RM, Blair-Reid SA, Pratt KM, Stone HR, Weekes D, Lawrence KJ, Morris JR: The deSUMOylase SENP7 promotes chromatin relaxation for homologous recombination DNA repair. EMBO Rep 2013, 14:975-983.

97. Rogakou EP, Pilch DR, Orr AH VSI, Bonner WP: DNA double-strand breaks induce H2AX phosphorylation on Serine 139. J Biol Chem 1998, 273:5858-5868.

98. Takahashi M, Koi M, Balaguer F, Boland CR, Goel A: MSH3 mediates sensitization of colorectal cancer cells to cisplatin, oxaliplatin, and a poly (ADP-ribose) polymerase inhibitor. J Biol Chem 2011, 286:12157-12165.

99. Saffhill $\mathrm{R}$, Ockey $\mathrm{CH}$ : Strand breaks arising from the repair of the 5-bromodeoxyuridine-substituted template and methyl methanesulphonate-induced lesions can explain the formation of sister chromatid exchanges. Chromosoma 1985, 92:218-224.

100. Rouleau M, Patel A, Hendzel MJ, Kaufmann SH, Poirier GG: PARP inhibition: PARP1 and beyond. Nat Rev Cancer 2010, 10:293-301.

101. Zaremba T, Curtin NJ: PARP inhibitor development for systemic cancer targeting. Anticancer Agents Med Chem 2007, 7:515-523.

102. Bryant HE, Schultz N, Thomas HD, Parker KM, Flower D, Lopez E, Kyle S, Meuth M, Curtin NJ, Helleday T: Specific killing of BRCA2-deficient tumours with inhibitors of poly(ADP-ribose) polymerase. Nature 2005, 434:913-917.

103. Tutt A, Robson M, Garber JE, Domchek SM, Audeh MW, Weitzel JN, Friedlander M, Arun B, Loman N, Schmutzler RK, Wardley A, Mitchell G, Earl $\mathrm{H}$, Wickens M, Carmichael J: Oral poly(ADP-ribose) polymerase inhibitor olaparib in patients with BRCA1 or BRCA2 mutations and advanced breast cancer: a proof-of-concept trial. Lancet 2010, 376:235-244.

104. Ang JE, Gourley C, Powell CB, High H, Shapira-Frommer R, Castonguay V, De Greve J, Atkinson T, Yap TA, Sandhu S, Banerjee S, Chen LM, Friedlander ML, Kaufman B, Oza AM, Matulonis U, Barber LJ, Kozarewa I, Fenwick K, Assiotis I, Campbell J, Chen L, de Bono JS, Gore ME, Lord CJ, Ashworth A, Kaye SB: Efficacy of chemotherapy in BRCA1/2 mutation carrier ovarian cancer in the setting of PARP inhibitor resistance: a multi-institutional study. Clin Cancer Res 2013, 19:5485.
105. Qian J, Luo Y, Gu X, Wang X: Inhibition of SENP6-induced radiosensitization of human hepatocellular carcinoma cells by blocking radiation-induced NF-KB activation. Cancer Biother Radiopharm 2013, 28:196-200.

106. Albrow VE, Ponder EL, Fasci D, Békés M, Deu E, Salvesen GS, Bogyo M: Development of small molecule inhibitors and probes of human SUMO deconjugating proteases. Chem Biol 2011, 18:722-732.

doi:10.1186/s13073-014-0068-4

Cite this article as: Tosti et al:: Evolutionarily conserved genetic interactions with budding and fission yeast MutS identify orthologous relationships in mismatch repair-deficient cancer cells. Genome Medicine 2014 6:68.

\section{Submit your next manuscript to BioMed Central and take full advantage of:}

- Convenient online submission

- Thorough peer review

- No space constraints or color figure charges

- Immediate publication on acceptance

- Inclusion in PubMed, CAS, Scopus and Google Scholar

- Research which is freely available for redistribution

Submit your manuscript at www.biomedcentral.com/submit
C) BioMed Central 